\title{
PRACTICAL TRAINING OF SECONDARY SCHOOL TEACHERS IN SPAIN: TUTORING AND ASSESSMENT USING ICT
}

\author{
Dr. Daniel MARTINEZ-ROMERA \\ ORCID: 0000-0003-4895-7955 \\ Faculty of Education, University of Cadiz \\ Puerto Real, SPAIN \\ Dr. Daniel CEBRIAN-ROBLES \\ ORCID: 0000-0003-4895-7955 \\ Faculty Education, University of Malaga \\ Malaga, SPAIN \\ Dr. Rafael PEREZ-GALAN \\ ORCID: 0000-0003-2443-8667 \\ Faculty Education, University of Malaga \\ Malaga, SPAIN
}

Received: 31/03/2019 Accepted: 06/05/2019

\begin{abstract}
This study is part of a larger $R \& D$ project that analyses the quality of training and the digital skills taught during the preservice training of teachers, as well as during the master's degree dissertation (TFM in Spanish) in the Degree in Education in Spain. The study is descriptive and exploratory in nature. It combines mixed techniques that are used on four sources: 1) External practice guides and dissertations (TFM) from 37 Spanish Faculties of Education; 2) interviews with a sample of 7 Master coordinators; 3) A survey on 94 university tutors from the above-mentioned universities, in charge of trainee teachers' external practice and dissertations (TFM); and 4) Interviews with 46 school tutors from practice schools. Results show the persistence of different situations and a lack of definition in the guidelines as well as in some teachers' perceptions that have more to do with educational models of the past. Among other aspects to improve, this degree shows a marginal use of ICT during Practicum and Dissertation phases, also a lack of assessment criteria in the guides regarding portfolios, theory/practice coordination, tutorship or prevention of plagiarism is observed in most of the studied cases.
\end{abstract}

Keywords: Preservice Training, Secondary Education, Tutoring, Assessment, Practicum, ICT.

\section{INTRODUCTION}

Spain has recently changed its model of teacher training. It consisted of a short course in the past and has become a full year Master's Degree in Teaching, fully implemented nowadays. Therefore, teacher education has been improved (Esteve-Zarazaga, 2009a; Gonzalez-Sanmamed, 2009, 2015), although it is not exempt of criticism (Esteve 2009b, Manso, 2011; Tiana, 2013, 2011). This achievement involved a lot of time analysing, discussing and suggesting basic concepts and opinions in relation to: objectives and scope (Gamez-Rebolledo, 2015; Cohen, Hoz \& Kaplan, 2013; Moon, 2006), theoretical and practical contents and their assessment (Hascher \& Hagenauer, 2016; Rorrison, 2010; Molina-Ruiz, 2008) or implementation itself (Grudnoff, Haigh \& Mackisack, 2016; Lawson et al., 2015; Garii, 2008; PapouliaTzelepi, 2006). Most of these aspects are reflected in the evidence gathered and outlined in the teaching guides, both during external practice and in the dissertation (TFM). The latter is a key tool that still needs more analysis in the Spanish context. 
From the very beginning, implementing this new model required introducing new challenges (ValdesPuentes, Bolivar-Botia \& Moreno-Verdejo, 2015), such as focusing on professionalising students or introducing quality standards in relation to the internal coherence of new courses, contents, assessment and elements to support both the Practicum and the dissertation (TFM) (Arribas-Estebaranz, Manrique-Arribas \& Tabernero-Sanchez, 2016; Hernandez-Pina, 2014; Gonzalez-Faraco, Perez-Moreno \& Jimenez-Vicioso, 2011).

This was such a challenge given some of the broad areas of the master's degree, such as Social Sciences, where students could come from Geography, History, Art History, Philosophy, Anthropology, Political Sciences or Journalism, to mention just the most common. It was also necessary to understand the difficulties and new responsibilities added to university tutors, school tutors and preservice teachers in their new, redefined roles (Serrano-Rodriguez \& Pontes-Pedrajas, 2015b; Gonzalez-Peiteado, 2014; Jimenez-Segura, 2013); plus, the background cross-curricular issue, i.e. how to combine theory and practice in the master's degree, in order to identify potential areas for improvement (Zabalza-Beraza, 2006).

Furthermore, in Spain, each region (i.e. each regional university) has a remarkable degree of freedom when interpreting the meaning of national laws and regulations, so each university reserves the right to add complementary courses or qualify criteria on content, assessment and tasks of preservice teachers. Therefore, interpreting and evaluating every university's master's teaching guides is relatively easy (Muniz-Rodriguez et al., 2016); but the analysis of these guides at a national level becomes much more difficult.

Although an exact definition of the structure of this Master is not possible for the reasons indicated, following Benarroch (2011) and Benarroch, Cepero \& Perales (2013) we can outline a general scheme on which all the Spanish education faculties pivot. Master's degree is arranged in three quarters:

First one is dominated by generalist contents, all students learn the basics about general pedagogy, educational psychology and school organization. Here it is also common to find subjects designed to introduce students to innovation and educational research.

The second one is more focused on each area of knowledge specialization. With subjects dealing with curriculum, contents development, assessment and didactical resources on their specialization areas. The main idea here is to introduce to the students the singularities and difficulties of the branch of knowledge of which they will be teachers in the future.

Then it comes the Practicum, external practice in high schools. The contact with the educational reality allows them a first-hand knowledge, at the same time that it offers them the possibility of putting into practice the theoretical knowledge acquired in the previous quarters. This phase included their first experience as teachers and ends with the completion of a practice report.

Finally, students end their Master's degree with a dissertation that usually covers all the phases of the Master, but with a clear emphasis on the revision and innovation of the teaching proposals developed during the Practicum.

In this sense, the challenge pointed out earlier need to be contrasted with the students' expectations along the course. Something that has only been studied through local or specific area-related approaches (Serrano Rodriguez \& Pontes Pedrajas, 2015a; Manso Ayuso \& Martin Ortega, 2014).

When we focus on ICT, the scientific literature is still scarce and suffers from the same limitations as the previous one, which must be taken into account. Nonetheless, frequently is pointed out limitations of implementation associated with the digital competence of teachers and the ICT resources limitation, especially in high schools, but also growth spaces through emerging technologies associated (Serrano Rodriguez \& Pontes Pedrajas, 2017; Roblizo Colmenero, Sanchez Perez \& Cozar Gutierrez, 2015; LopezMeneses, Dominguez Fernandez, Alvarez Bonilla \& Jaen Martinez, 2011).

\section{METHODOLOGY}

The present study is part of a larger project [1] that analyses the use of Information and Communication Technologies (ICT) in the assessment and tutoring of students of the Master's Degree in Secondary Education and Teacher Training in Spain; in the schools where they carry out their external practice. 
The design of the research is mixed-methods design (qualitative-quantitative), exploratory, with four sources of information (coordinators of training programmes, teaching guides, university tutors and school tutors). It uses different techniques for collecting information (surveys, content analysis and interviews) and for conducting data analysis (categorical analysis and statistical treatment). This relatively complex structure is shown in Table 1.

The study ultimately aims at analysing the model used and the nature of external practice, as well as the internal coherence and integration of these aspects in the assessment conducted with ICT. To do so, the research is divided into four dimensions, which are cross-related and respond to the tutoring and assessment of learning in the Practicum and dissertation (TFM) of the Master's Degree in Secondary Education. The dimensions are: a) the nature and management of practice; b) the process of tutoring and assessment; c) the technological support used; and d) the ethics of assessment.

\section{Population and Sample}

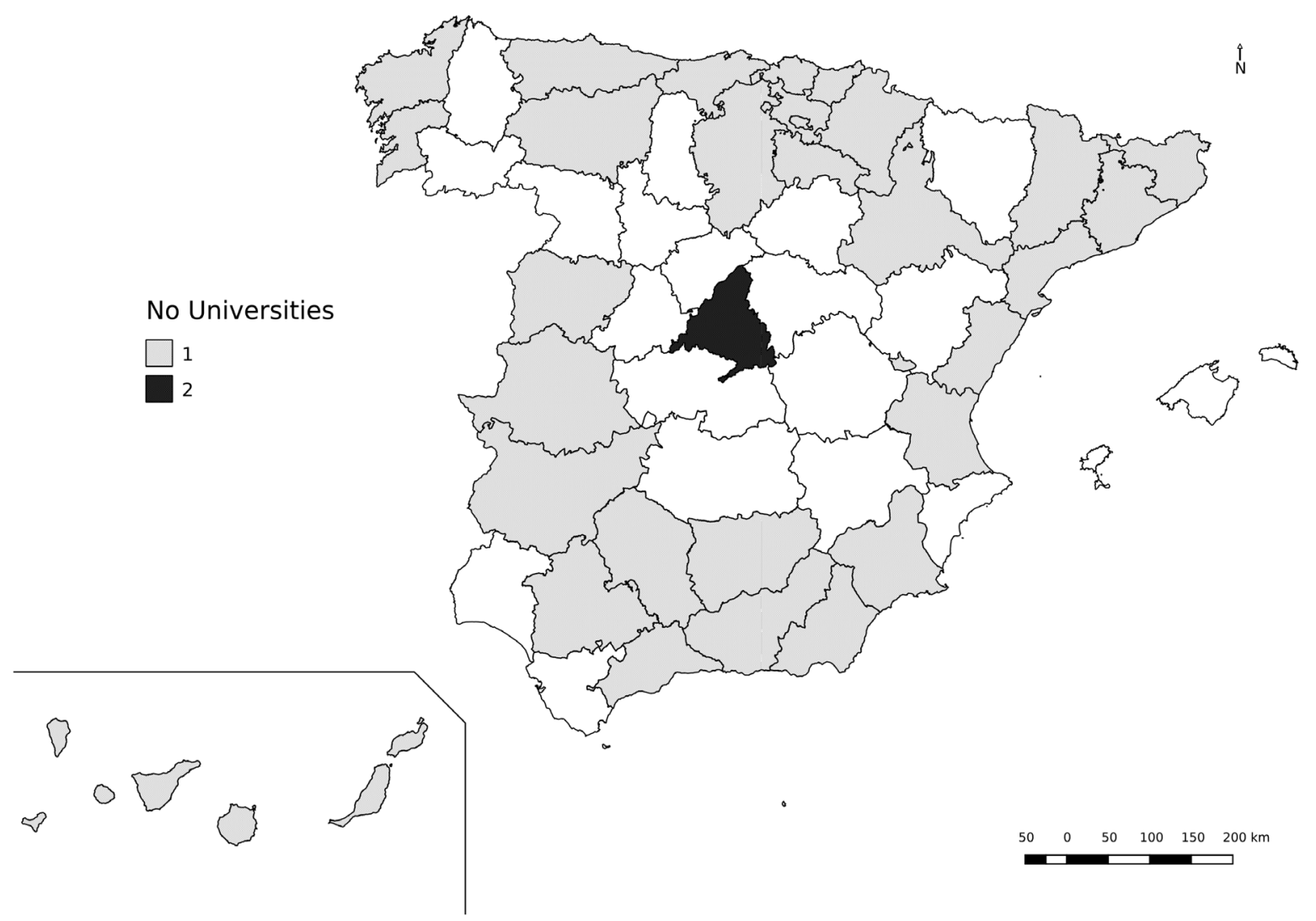

Figure 1. Spatial coverage of the research

Information was collected through different methods and from a number of samples, depending on the source. The Spanish university system consists of 83 universities, 50 of which are state-owned and the rest are privately owned, the spatial coverage of the study is shown in Figure 1. Considering the size of the reference population and the representativeness of the samples collected, the study obtained different degrees of coverage, which are explained in Table 1. 
Table: 1 . Sequence of objectives in the study

\begin{tabular}{lllr}
\hline \multicolumn{1}{c}{ Objective } & \multicolumn{1}{c}{$\begin{array}{c}\text { Population } \\
\text { and Sample }\end{array}$} & Data Collection Technique & \multicolumn{1}{c}{$\begin{array}{c}\text { Variable } \\
\text { Percentage }\end{array}$} \\
\hline $\begin{array}{l}\text { 1. Analysis of teaching } \\
\text { guides. }\end{array}$ & $\begin{array}{l}\text { 391 guides from 376 state- } \\
\text { owned universities. Final sample } \\
\text { of 60 guides selected from 34 } \\
\text { Faculties of Education in Spain. }\end{array}$ & $\begin{array}{l}\text { Collecting guides on external } \\
\text { practice and dissertations } \\
\text { (TFM) }\end{array}$ & $\begin{array}{r}\text { 74\% of state- } \\
\text { owned Faculties of } \\
\text { Education in Spain. }\end{array}$ \\
$\begin{array}{l}\text { 2. Interviews with practice } \\
\text { programme coordinators. }\end{array}$ & $\begin{array}{l}54 \text { coordinators, } 7 \text { of whom are } \\
\text { coordinators from the Masters } \\
\text { Degree in Secondary Education. }\end{array}$ & $\begin{array}{l}\text { Strategic sampling (Perello, } \\
2009: 27)\end{array}$ & $\begin{array}{c}13 \% \text { of } \\
\text { coordinators }\end{array}$ \\
$\begin{array}{l}\text { 3. Interview with university } \\
\text { tutors. }\end{array}$ & $\begin{array}{l}\text { 48 tutors of Faculties of } \\
\text { Education. }\end{array}$ & Interviews by appointment & $100 \%$ \\
$\begin{array}{l}\text { 4. Interview with school } \\
\text { tutors. }\end{array}$ & $\begin{array}{l}\text { 46 tutors from schools where } \\
\text { students do their external } \\
\text { practice. }\end{array}$ & Interviews by appointment & $100 \%$ \\
\hline
\end{tabular}

Note: Own elaboration.

\section{Instruments and Analysis Techniques}

The instruments and validation procedures used are as follows:

In relation to the first objective, a registration form was used to analyse teaching guides, together with a questionnaire for the interviews with external practice coordinators, university tutors and school tutors. The survey was designed by members of the research team according to the Delphi technique (Okoli \& Pawlowski, 2004; Patton, 1987). Survey indicators were grouped into categories (Tejada-Fernandez, Serrano-Angulo, RuizBueno \& Cebrian-Robles, 2015). The resulting data was calculated using three techniques: a) The judgement of 14 experts who used the criteria of relevance and univocity, based on the Kcomp Coefficient of Competence (Martinez, Zúniga, Sala \& Melendez, 2012). Results in all cases showed an average experience of more than 0.09 points. b) A discussion group (Krueger, 1991) of 12 researchers from 9 universities linked to the project. c) A pilot application of the instrument to 10 cases in the population context. In relation to content validity (CVR), Lawshe's formula (1975) was applied to all items. Results showed a value of 0.736 , above the minimum recommendations given by the author (between 0.51 and 0.57 ). Based on the above results, an instrument was designed to analyse guides. The instrument consists of 44 items, based on the aforementioned dimensions and aims at analysing the Practicum and dissertation (TFM) guides. The content of teaching guides and interviews with programme coordinators was analysed through categories of analysis, following the "Q-analysis" technique (Buendia-Eisman, Colas-Bravo \& Hernandez-Pina, 1998, pp. 317-319).

In relation to the second objective, survey data was analysed using the SPSS V.23. The final questionnaire for coordinators' interviews includes 80 items with an internal consistency of Cronbach's Alpha of 0.72 . With regards to the third objective, university tutors' questionnaire included 28 items. As for the fourth objective, school tutors' questionnaire includes 6 items, the latter being "choose from the indicators that you most use to assess your students".

\section{ANALYSIS OF MAIN RESULTS}

\section{Type of Guide and Associated Regulations}

From the 60 guides analysed, 32 (53.3\%) correspond to External Practice and 28 (46.7\%) to dissertations (TFM). It is worth noticing that only $3.3 \%$ of the guides explicitly refer to current national regulations, such as Spanish Royal Decree 1027/2011 and Spanish Order ECI/3858/2007 on the new model of Master's Degree in Professional Teacher Training. The values are higher (51.7\%) when it comes to basic and general competences in Education, established in Spanish Royal Decree 1393/2007 and regarding specific competences in postgraduate courses $(78.3 \%)$. A relevant aspect of this study focuses on knowing whether there is coordination between theory and practice. However, in $51.7 \%$ of the guides, there is no explicit evidence of such coordination. 
Considering the treatment given to the Practicum by the different regulations for Master's Degrees, the poor response given by university coordinators to regulations on the assessment (28.6\%), methodology (28.6\%) and criteria (28.6\%) of the Practicum is striking. Regulations on the Practicum improve only slightly when the object of assessment is the dissertation (TFM), shown in $57.1 \%$ (assessment), $42.9 \%$ (methodology) and $42.9 \%$ (criteria).

\section{Number of Credits and Teaching Distribution}

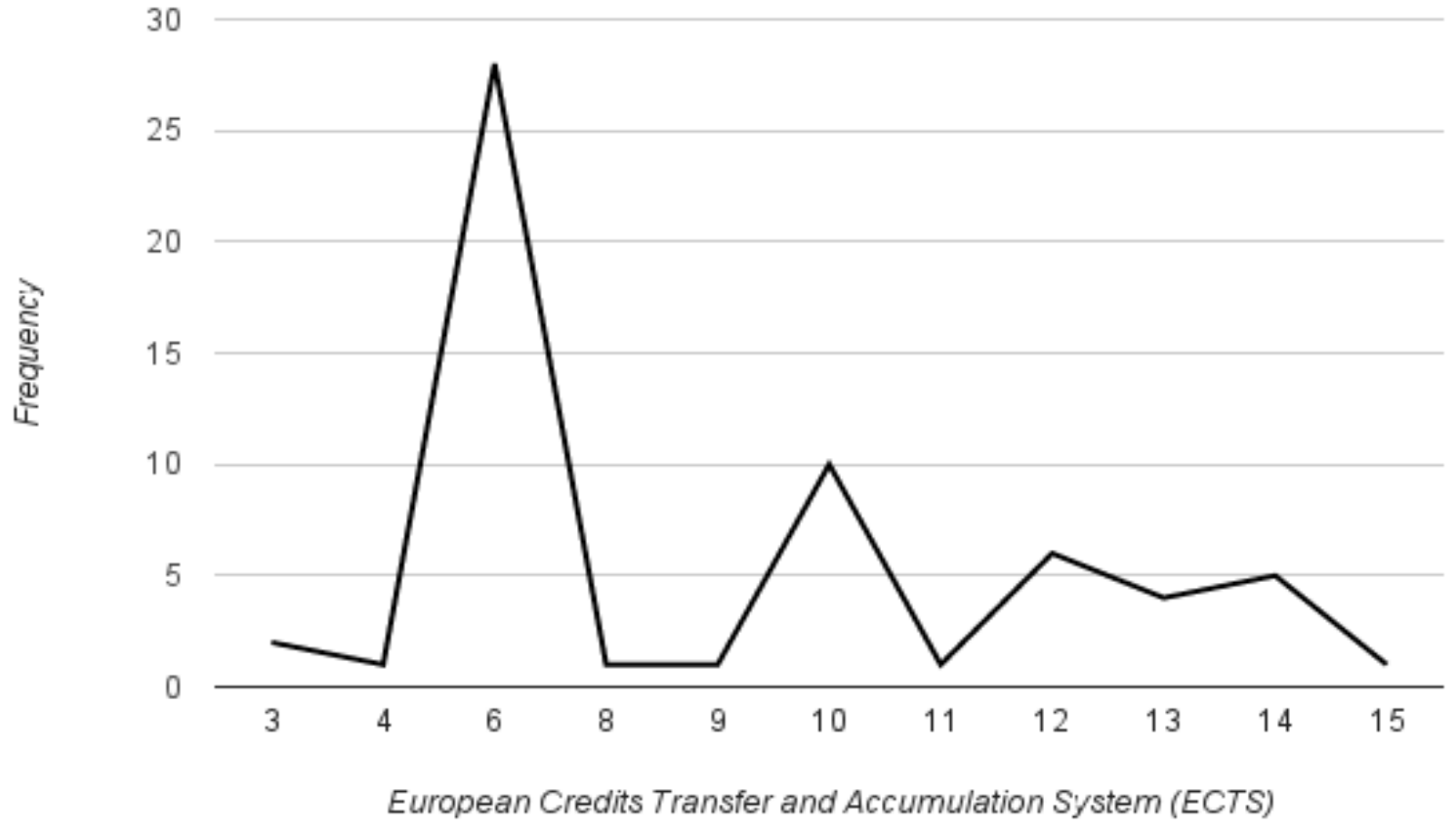

Figure 2. ECTS (European Credit Transfer System) for Practicum and Dissertation (TFM).

As observed in Figure 2, 46.6\% of guides opt for a 6 ECTS model of practice, although the rest of guides give 10 or more ECTS to practice, representing $45 \%$ of all guides. This shows a clear duality in the conception of the teacher, strained between a more theoretical-academic traditional model in which practice is complementary, and a more practical and modern model in which practice becomes essential to learn the profession. All guides contemplate a 1 ECTS $=25$ hours of dedication ratio. However, the internal distribution between dedication and attendance is not clear. This is shown by the lack of response in the survey, which does not exceed $15 \%$ with regards to dedication but rises to $45 \%$ regarding attendance.

This fact is reflected in the lack of coordinators' response to questions related to university tutors' hours of dedication to planning, managing and assessing external practice or dissertations (TFM). In the latter case, the estimated hours of dedication are only 3. Additionally, the number of students per tutor at this stage (external practice and dissertations) should not be estimated a priori $(57.2 \%)$, as it reveals clearly different values afterwards: $28.6 \%$ of tutors have 2 students, whereas $14.3 \%$ of tutors have 6 . On a different matter, most guides (71.4\%) consider that for tutors to supervise trainee teachers, they must be teaching in the Master's Degree or have experience in Secondary Education or Vocational Training (42.9\%), an interest in a thematic line $(14.3 \%)$ or have accepted the teaching allocation by the Department $(14.3 \%)$.

\section{External Practice}

$61.7 \%$ of the guides do not specify the number of hours that practice should involve and only $31.7 \%$ of them explicitly refer to the link between Practicum and dissertation (TFM). This trend persists when looking at face-to-face seminars, for which only $11.7 \%$ of the guides establish a mandatory minimum (from 1 to 4 seminars). This situation shows the limited definition of the number of hours allocated to face-to-face seminars $(15 \%)$ and online seminars $(1.7 \%)$. 
Both coordinators and university tutors stress a total lack of specific training and planning activities and almost a total lack of assessment (85.7\%). This lack of definition also affects coordination activities between school tutors and university tutors. Coordination activities are only mentioned in one case, and only with regards to training aspects. While coordination between university tutors is not contemplated, university tutors and coordinators are supposed to be coordinated in relation to: planning $(57.1 \%)$, common assessment criteria $(28.6 \%)$ and other aspects $(28.6 \%)$, such as opening up to databases and creating assessment rubrics. This lack of definition is also common to students' documents (practice reports, learning journals, lesson plans, portfolios and teaching units), for which $85.7 \%$ of coordinators do not select a specific type of evidence.

Although $25 \%$ of the guides establish Practicum in the second semester of the year and $21.7 \%$ of the guides place it during the entire year, there is still a $53.3 \%$ of the guides that do not mention the period of time during which the Practicum should take place. Likewise, there is no definition regarding learning assessment in the guides and a strikingly scarce reference to rubrics (5\%), a lack of estimations of the workloads assigned to portfolios (78.3\%) and a lack of time estimations for personal work at this stage (76.7\%).

Therefore, learning assessment is relatively blurred in the guides, which only include a definition in $36.6 \%$ of cases, and when they do, this definition repeatedly focuses on: collaboration (16.7\%), observation (6.7\%), intervention (5\%) and variable combinations (8.3\%). As for evaluators (university and school tutors), they enjoy a wide range of weight in assessing: 30 to $75 \%$ in the case of university tutors and 25 to $70 \%$ in school tutors. However, cumulative frequencies have shown that the weight of both tutors tend to achieve $50 \%$, although there is a slight positive bias towards school tutors.

Nor do guides outline the assessment criteria to be applied to portfolios or practice reports, with the most recurrent skills being: thoughts on the experience (8.3\%), applying theory to analysis (3.3\%) and other skills without general recurrence (15\%). Likewise, the weights of the different tasks are vaguely defined. The most controlled task is portfolios ( 25 to $50 \%$ weight, with a tendency to the lower end), followed by face-to-face seminars (10 to $25 \%$ weight).

With regards to evidence, the guides highlight: attendance and degree of integration, interest, participation and collaboration in seminar tasks; although the weight given to all of them is less than $10 \%$ in the guides, which do not give much detail, either. Honour distinctions are only defined in $5 \%$ of cases, as they are generally not explicitly addressed in the guides. This is also the case with external practice, regarding organisation and competences.

In relation to university and school tutors, the above situation improves. $21.7 \%$ of the guides list their functions, although only one guide explicitly defines allocation criteria for tutors. Regarding issues related to ethics, control and management of practice reports, this study did not find any mention of the registration, custody, publication, intellectual property, industrial exploitation, plagiarism or any other agreement in the selected guide sample.

\section{Dissertation (TFM in Spanish)}

The dissertation or TFM is considered an individual task in $20 \%$ of the guides and is accepted as a group task in only one case. The rest of the guides do not explicitly mention the dissertation (TFM). The same ambiguity is found regarding its typology and nature, and no guide defines it as an intervention project.

Nonetheless, coordination and control of this stage in the Master's Degree are clearly more addressed than the previous one. The use of online platforms or email is explicit in $57.1 \%$ of the guides. Furthermore, for a Dissertation (TFM) to be uploaded to an institutional repository, it has to obtain the university tutor's approval (42.9\%), student's approval (42.9\%) and be graded as excellent (4.3\%). However, there is no consensus on how to control intellectual property issues and plagiarism, and $57.1 \%$ of respondents state that it is up to each tutor to do so. Overall, $71.5 \%$ of coordinators are satisfied or quite satisfied with the assessment model applied at this stage.

Access to the dissertation (TFM) is scarcely defined in terms of the minimum number of credits required to enrol. Only two guides set this number in 54 and 90 credits, respectively. As for the type and nature of dissertations (TFM), 16.7\% of the guides address the research approach in them, $11.7 \%$ the innovation one, $3.3 \%$ the intervention one, $3.3 \%$ the bibliographic review and $16.7 \%$ address other proposals. However, all the descriptions end up more or less integrated with the concepts of classroom curriculum design and teaching lesson. 
Nonetheless, less than $5 \%$ of the guides define the guidelines to allocate university tutors, their functions, their student ratio, the specific research lines they can work on, as well as registration guarantees, custody and publication of dissertations (TFM), plagiarism control, confidentiality agreements or the role of institutional repositories. The same thing goes for the public defence, content and structure of dissertations (TFM), their theoretical foundation, bibliographic relevance, technological resources used, the decision to grant high honors or the procedure for appointing panels and their competence. The above aspects are conspicuous by their absence in $63.3 \%$ of the guides.

The assessment weighting at this stage shows great heterogeneity: 15 guides grant from 20 to $100 \%$ weight to the dissertation (TFM) in relation to the Practicum; although 60\% of guides opt for a balance between both, granting $50 \%$ or $60 \%$ weight to each. Something similar happens with defending the dissertation (TFM) before a panel, which is given a weight of 15 to $85 \%$ of the final mark; although 10 out of 15 guides grant a 30 to $50 \%$ weight to the panel's assessment. Other relevant aspects are gathered in 5 guides, which grant from 5 to $20 \%$ weight to these aspects. All of this goes without forgetting that most guides (75\%) do not specify the assessment weighting in their pages.

\section{University Tutors}

Six universities participated in this survey, which involved tutors of trainee teachers' external practice and dissertations (TFM). The survey collected 94 questionnaires: 46 from external practice tutors and 48 from dissertation (TFM) tutors. Regarding the latter, tutors had very different professional levels, from full professors to interim teaching staff, where $68.75 \%$ of them were not civil servants. Moreover, they came from 10 different areas of knowledge, including Social Sciences, Experimental Sciences, Mathematics, Didactics and School Management, Diagnosis Methods and Educational Research or Theory and History of Education.

Tutors' age ranged from 30 to 69 years, with a fairly linear distribution and a clearly masculinised ratio (1.43). Professional experience was assessed based on 1) years of teaching and 2) years of tutoring the dissertation (TFM). As for years of teaching, responses ranged from 1 to 45 years, with a higher rate from 6 to 20 years. As for years of tutoring the dissertation (TFM), most tutors have been doing so from 1 to 32 years, although $74.5 \%$ of them have done so for no more than 7 years.

In terms of workload, each tutor takes in 1 to 32 trainee students (in external practice), although $87 \%$ of tutors take 8 or less and $71.7 \%$ take less than 6 . Regarding the distribution of dissertations (TFM), $52.1 \%$ of tutors take 1 or 2 dissertations (TFM) and $83.3 \%$ take 3 to 6 .

A striking fact regarding the link between external practice and dissertation (TFM) is that only $69.5 \%$ of university tutors perceive there is an actual link. Despite the high percentage, it is still insufficient if we take into account that the Master's Degree in Teaching should aim at professionalising students; so this is an aspect we clearly need to keep working on. In any case, external practice is usually carried out in state-owned schools (86.4\%) and only sometimes in private schools.

The types of dissertations (TFM) are very varied: intervention, research, innovation, bibliographic review or theoretical essay. However, the most common types (92.2\% of cases) are: $38.9 \%$ for intervention, $31.1 \%$ for research and $22.2 \%$ for innovation.

As for the type of tutoring during the external practice period, both face-to-face and online tutoring are common. Regarding the former, face-to-face tutoring sessions are usually arranged from 1 to 8 times, although it is uncommon to have more than 6 sessions. With regards to online tutoring, sessions increase from 1 to 18 , with $75.8 \%$ of tutors reporting 6 or less sessions; although it should be noted that online tutoring includes both synchronic and diachronic communications.

In relation to dissertations (TFM), the frequency increases. Face-to-face tutoring can involve up to 12 sessions, although $80.4 \%$ of tutors only use 6 sessions or less. Online tutoring involves up to 25 sessions, although $83.7 \%$ of tutors reported using 10 sessions or less. 


\section{School Tutors}

From the 46 teachers participating in this survey, $69.6 \%$ belonged to state-owned schools and the rest to private schools. The most common type of school was high schools $(73.9 \%)$, whereas the rest were educational companies, institutions and associations. School tutors' age range from 27 to 60 years, although more than half $(52.3 \%)$ of them are 48 or older, with a very balanced sex ratio (0.95).

Their teaching experience ranges between 3 and 35 years, with $53.5 \%$ of them having over 23 years' experience. Regarding tutoring experience, teachers reported having between 1 and 26 years' experience, although $52.4 \%$ of them have 3 years or less. They can tutor up to 5 students in a year, although the vast majority is responsible for $1(72.7 \%), 2(9.1 \%)$ or $3(13.6 \%)$ students.

Table 2 shows the relevance (in decreasing order) of the use of evidence established to assess the teaching practice of trainee teachers.

Table: 2. Relevance of evidence for assessing trainee teachers.

\begin{tabular}{|c|c|c|c|c|}
\hline \multirow[b]{2}{*}{ Evidence } & \multicolumn{4}{|c|}{ Assessment } \\
\hline & $\begin{array}{l}\text { Not } \\
\text { at all }\end{array}$ & A little bit & Quite & A lot \\
\hline Respect of standards & & & 4.5 & 95.5 \\
\hline Professional treatment of students & & & 9.1 & 90.9 \\
\hline Assertiveness in assigned tasks & & & 9.1 & 90.9 \\
\hline Responsibility at work & & & 9.1 & 90.9 \\
\hline Punctuality & & & 13.6 & 86.4 \\
\hline Implication in tasks & & & 13.6 & 86.4 \\
\hline Teacher integration & & 4.5 & 13.6 & 81.8 \\
\hline Teamwork skills & & & 19.9 & 81.0 \\
\hline Compliance with the schedule & & & 22.7 & 77.3 \\
\hline Delivery of tasks on time & & & 22.7 & 77.3 \\
\hline Use of information related to practice & & 9.1 & 13.6 & 77.3 \\
\hline Appropriate planning and intervention design & & 13.6 & 9.1 & 77.3 \\
\hline Successful completion of tasks & & & 23.8 & 76.2 \\
\hline Use of ICT & & 18.2 & 9.1 & 72.7 \\
\hline Preparation of tasks & & 4.8 & 23.8 & 71.4 \\
\hline Properly formalised tasks & & & 31.8 & 68.2 \\
\hline Problem solving & & 4.5 & 27.3 & 68.2 \\
\hline Promote equity and equality & & 4.5 & 27.3 & 68.2 \\
\hline Initiative taking & & 13.6 & 18.2 & 68.2 \\
\hline Involvement in school activities & 5.0 & 15.0 & 15.0 & 65.0 \\
\hline Attention to diversity & & 4.5 & 31.8 & 63.6 \\
\hline Mastering the curriculum and the programme & & 18.2 & 18.2 & 63.6 \\
\hline Demonstrated digital competence & & 19.0 & 19.0 & 61.9 \\
\hline Knowledge of the school bodies & & 23.8 & 19.0 & 57.1 \\
\hline Tutor involvement & & 31.6 & 15.8 & 52.6 \\
\hline Relationship with the families & 12.5 & 31.3 & 18.8 & 37.5 \\
\hline
\end{tabular}

Note: Own elaboration.

It is worth noticing that highly valued evidence above 90 points corresponds to traditional functions of teaching, which can be summarised in the conception of the teacher as "the good manners icon" (respect of standards, professional treatment of students, assertiveness, responsibility, punctuality, etc.). For instance, the evidence that has to do with trainee teachers' group skills is found in the 7th and 8th position and refers to their ability to integrate into the teaching community and work groups, respectively.

In the intermediate positions, we find evidence related to the work prior to teaching and teaching skills: lesson planning and design, use of ICT, preparation of tasks and, in a less important position, the promotion of gender equality. Altogether, all evidence is fairly valued, ranging from 68.2 to 77.3 points. The less important position of evidence on gender equality is noteworthy, as this is one of the most important functions required from future teachers nowadays. 
The least valued evidence in this category (below 68.2 points) has to do with the introduction of new responsibilities, such as attention to diversity; to a lesser extent, tutoring involvement and in the last position, relationship with families. Evidence also shows low scores in "Quite", "A little bit" and "Not at all", which are related to classic evidence, such as mastery of the curriculum, knowledge of the school and digital competence.

In relation to school tutors, regardless of how exceptional some responses in Table 2 are - such as the fact that some trainee teachers do not consider it relevant to get involved in school activities (5.0 points) or their relationship with families (12.5 points), there are some groups of skills that have been given the appropriate importance in line with the conception of the teacher, at least since the arrival of democracy in Spain.

In this sense, this study found some item correlations in school tutors' assessment in relation to evidence in Table 2. Thus, school tutors who emphasise the importance of tutoring work also consider the channels of communication with families to be relevant $(79.4 \%)$; those who emphasise the importance of meeting diversity needs also consider it essential to be documented before the class $(75.5 \%)$; and those who stress the need to be documented before class mostly expect students to carry out the task successfully (74\%).

\section{DISCUSSION AND CONCLUSIONS}

In general terms, teaching guides lack detail when defining important aspects of the organisation between tutors and students, especially regarding the number of trainee teachers allocated to each university tutor and important specifications about both face-to-face and online seminars, since the values found are low or very low. The same thing applies to the university and school tutor coordination and the training received by school tutors. However, the planning and assessment between tutors and coordinators is made perfectly clear in the guides.

As for the use of ICT in the Practicum, 28.6\% of university tutors use email and online platforms, although they do not mention any specific criteria to do so. However, this is a low percentage when compared to the rest of university tutors from all other degrees in Spanish Faculties of Education, where the use of ICT accounts for 50\% (Bartolome-Pina, Canton-Mayo \& Moral-Ferrer, 2017). Nonetheless, this low percentage makes sense in this study, where tutors rarely use any other technology for tutoring and evaluating learning.

The above situation is in line with the lack of detail in defining practice reports. The tutoring methodology and "authentic" assessment of trainee teachers' practical learning are key aspects in the training of preservice teachers (Zeichner \& Wray, 2001, pp. 620). Here, the portfolio plays a crucial role as a guide to reflect trainee teachers' thoughts on their own learning experience (Toom, Husu \& Patrikainen, 2015, pp. 323). The assessment criterion of portfolios is testimonial: thoughts on the experience are the most frequent criteria and it only appears in $8.3 \%$ of the guides.

The short period of external practice in the training of preservice teachers - compared to other degrees in education that keep external practice for 2 or 3 years - seems to be one of the reasons behind trainee students rarely using ICT in their training period, which clearly limits their opportunities to internalise ICT in their future professional practice.

This shortage could be compensated if the training period (external practice) was not so short and Practicum was a year course, which only happens in $21.7 \%$ of the guides. Regarding dissertation (TFM) guides, the use of email and online platforms increases $(57.1 \%)$, as well as university tutors' requirements to upload dissertations (TFM) to institutional repositories (42.9\%).

$87 \%$ of university tutors are in charge of 8 students during their external practice, whereas $83.3 \%$ are responsible for 6 or less students in their dissertation (TFM). Although most tutors take in up to 8 students in both cases, there is an important percentage of tutors exceeding this number, which makes it difficult to use a portfolio methodology and a quality communication based on technology.

More than half of the school tutors $(52.3 \%)$ are 48 or more years old and $53.5 \%$ of them have 24 or more years' experience tutoring the Practicum. The allocation of trainee teachers to school tutors is well defined in the guides: 1 (72.7\%), $2(9.1 \%)$ or $3(13.6 \%)$. Among the assessment criteria used in the study, these tutors value very highly (above 86.4 points) the traditional functions of teaching, namely, "the teacher as the good 
manners icon". On the contrary, it is striking to note that the least valued assessment criteria are: relationship with the family, tutor involvement, knowledge of the school bodies and demonstrated digital competence (all of which scored 37.5 to 61.9 points).

As for issues related to assessment ethics, control and management of practice reports, no specific mention to intellectual property and control of plagiarism is found in the selected guide sample, in line with other studies (Cebrian-Robles, Raposo-Rivas \& Sarmiento-Campos, 2016, pp. 179). In any case, such mention would not be enough to guarantee an ethical and comprehensive training of trainee teachers in the good use of ICT. Likewise, when asking coordinators about the prevention of plagiarism and the steps to be taken in this direction, $51 \%$ of them state that there are no homogeneous criteria to prevent plagiarism as it is up to each university tutor to do so. Additionally, the visibility of the production of students' work in institutional repositories is a matter of little attention in the guides (3.6\%), in line with other studies on all degrees in Education (Cebrian-Robles, Raposo-Rivas \& Sarmiento-Campos, 2016, pp. 170).

Thanks to the coverage of this research over the country, we are now in a better disposition to see the bigger picture about this Master's degree. Thus, it has been observed that the shift from a small didactic course to a full master degree has had a positive effect in all the cases, shrinking the gap between universities theoretical point of view and the high schools' practical requirements.

On the other hand, the weaknesses detected here are consequence of common practices among universities, making it much easier to overcome them. Here, we must emphasize the need for better definition about how ICT could be used during the Practicum in communication, teaching and assessment processes. Also, it is clear that ICT cannot be understood in terms of personal computers and digital blackboards, nowadays students are native digital, and they use devices like smartphones more a more. Here, modern teacher have an opportunity to show how to take advantage of the devices under an educational and intellectual purposes. So they also need be trained for that.

The traceability of the use of ICT in the different master guides studied is difficult to perform. The digital competence is only clearly defined in reference to the theoretical subjects explicitly related to educational innovation, and to a lesser extent with educational research. But this is not the case with the Practicum and Dissertation guides. However, both the analysis of the guides and the questionnaires reveal the need to specify the relevance of ICT and increase its presence in all phases of the Master:

The virtual seminars are specified in only one of the analysed guides, so their national implementation is far from optimal. The projection of the Dissertation towards institutional digital repositories is clearly defined in one guide, in the rest this is not done or is limited to posing it as a possibility in which criteria or procedures are not specified for it.

When programme coordinators are asked about the technological supports used in the monitoring and evaluation of the external practices, only $28.6 \%$ clearly recognize their use, although to refer it to the use of email; so that such relevant and current possibilities as the use of ePortfolio, eRubric or Social Networks are null, or cited but without specifying criteria of use.

This explains one of the main contradictions found in the use of ICT: practically all guides refer to the use of the virtual campus as the backbone of the training process in the theoretical phase, but it is completely blurred during the Practicum and the Dissertation.

In conclusion, whether due to slow dynamics associated with old-fashioned conceptions or discrepancies on the educational drift, the fact is that the low scores of school tutors in their assessment criteria, the lack of definition in the guides regarding portfolio methodologies and the still insufficient coordination between theory and practice (51.7\%), are pretty much in line with other studies (Gonzalez-Sanmamed, 2015, pp. 310). The above scenario clearly describes the elements that are needed in the design of teaching strategies to improve the training of preservice teachers: promotion of ICT and digital competence, a greater approach to school bodies and more attention to relationship with the families. Without this type of actions, it will be difficult to overcome the gap between teacher training and the change demanded in secondary education schools.

Authors' Note: R+D+i Spanish Plan Project 2014-17. Study of the Impact of Federated eRubrics on Assessing Competences in the Practicum. R+D+i Spanish Plan for Excellence, No. EDU2013-41974P. Website: http://goo.gl/u07aNs 


\section{BIODATA and CONTACT ADDRESSES of AUTHORS}

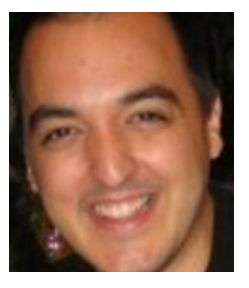

Dr. Daniel David MARTINEZ-ROMERA, is Assistant Professor in the Faculty of Education at the University of Cadiz, accredited as an Associate Professor. PhD in Education from the University of Malaga, PhD in Geography from the University of Granada and international postgraduate in Geographic Information Systems from UNIGIS International University. From 2005 to 2010, he was a trainee researcher and a PhD researcher at the Andalusian Institute of Statistics and Cartography, within an agreement with the University of Granada. His main lines of research are: Geography, Social Sciences and Teaching; Development and Innovation of ICT Applied to Teaching. An example of his work is the Diagrom teaching and analysis assistants (on ombrothermic diagrams) and Piradem assistants (on population pyramids); both available on his personal website. He also conducts quantitative and qualitative analyses of educational contexts and assessment processes supported by ICT.

Daniel David MARTINEZ-ROMERA

Department of Didactics, Faculty of Education

University of Cadiz, Campus de Puerto Real, ZIP 11519, Puerto Real (Cadiz), Spain

Phone: +349521326 04,

E-mail: danieldavid.martinez@uca.es

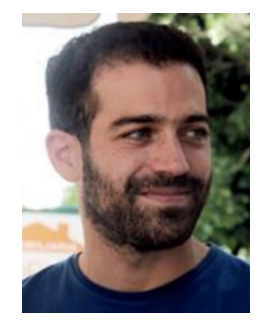

Dr. Daniel CEBRIAN-ROBLES, Industrial Engineer, Master's and $\mathrm{PhD}$ in Renewable Energies and Fluids, Master's in New Technology Applied to Education, $\mathrm{PhD}$ in Education with an Educational Research and Innovation Programme. Interim Substitute Professor at the University of Malaga. Member of the ENCIC Group and developer of a number of federated tools for Teaching, such as eRubric, CoRubric, Webquest and Multimedia Annotation Tools such as OVA, the latter integrated into the edX MOOC Platform. Research Fellow at Harvard University (USA) in 2013 and Research FellowMIT (USA) in 2016. He has given teachers plenty of lectures, conferences and workshops on the use of CoRubric and Open Video Annotation, thus contributing to improve teaching in some Spanish universities (Malaga, Almeria, Granada, Vigo, Madrid, etc.) and some universities abroad (Ecuador, Mexico, Paraguay, MIT -USA-). Personal website: http://danielcebrian.com.

\section{Daniel CEBRIAN-ROBLES}

Department of Didactics of Mathematics, Social and Experimental Sciences., Faculty of Education Address: University of Malaga, Campus de Teatinos, ZIP 29010, Malaga, Spain.

Phone: +34951952626,

E-mail: dcebrian@uma.es

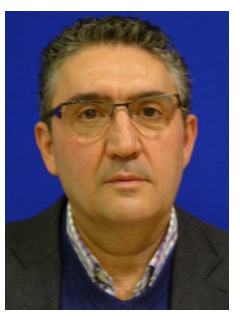

Dr. Rafael PEREZ-GALAN, has Diploma in Primary Education, Bachelor in Educational Sciences and Doctor of Pedagogy at the University of Malaga. Since 1993, he has been a professor in Antequera Graduate School of Education (CAMMIA) and an associate professor in the Department of Didactics and School Organisation at the University of Malaga since 2002. Coordinator of Practicums and Dissertations, member of the management team at the Board and Quality Committee in the Antequera Graduate School of Education. He also works for the GTEA Group (Research Group on Globalisation, Technology, Education and Learning) at the University of Malaga, as an educational researcher. He is also a researcher in the area of Attention to Diversity and Development of New Technologies applied to people with functional diversity (TAD), in view of their academic and social inclusion. He has written some books and plenty of articles on the improvement of the quality of life for people with ADHD. He currently works in the Research and Development Project (National Plan of Excellence (2014-2017) number EDU201341974-P. He also studied the impact of federated eRubrics on evaluating competence in the Practicum.

\section{Rafael PEREZ-GALAN}

Department of Didactics and School Organization, Faculty of Education

Address: University of Malaga, Campus de Teatinos, ZIP 29010, Malaga, Spain.

Phone: +34952132480,

E-mail: rpg@uma.es 


\section{REFERENCES}

Arribas-Estebaranz, J. M., Manrique-Arribas, J. C. \& Tabernero-Sanchez, B. (2016). Instrumentos de evaluacion utilizados en la formacion inicial del profesorado y su coherencia para el desarrollo de competencias profesionales en los estudiantes: vision del alumnado, egresados y profesorado [Assessment Instruments Used in Teacher Training and their Coherence for Developing Professional Skills in Students: A Perspective from Graduates and Professors]. Revista Complutense de Educacion, 27(1), 237.

Bartolome-Pina, A., Canton-Mayo, I. \& Moral-Ferrer, J.M. (2017). Una revision a los practicum de la educacion desde las tecnologías [A Technology Review of Education Practicums]. Practicum, 1(1) 40-53.

Benarroch, A., Cepero, S., \& Perales, F. J. (2013). Implementacion del Master de Profesorado de Secundaria: Metodologia y resultados de su evaluacion. Revista Eureka sobre Ensenanza y Divulgacion de las Ciencias, 10(nº extra), 594-615.

Benarroch Benarroch, A. (2011). Diseno y desarrollo del master en profesorado de educacion secundaria durante su primer ano de implantacion. Revista Eureka Sobre Ensenanza Y Divulgacion De Las Ciencias, 8(1), pp. 20-40.

Buendia-Eisman, L., Colas-Bravo, P. \& Hernandez-Pina, F. (1998). Metodos de investigacion en psicopedagogia [Methods of Research in Psychopedagogy]. Madrid: McGraw-Hill.

Cebrian-Robles, V., Raposo-Rivas, M. \& Sarmiento-Campos, J. A. (2016). Ethical or Dishonest Practices? Plagiarism Degrees in Education. Revista de Educacion, 374, 0. DOI: 10.4438/1988-592X-RE2016-374-330

Cohen, E., Hoz, R. \& Kaplan, H. (2013). The Practicum in Preservice Teacher Education: A Review of Empirical Studies. Teaching Education, 24 (4), 345.

Esteve-Zarazaga, J. M. (2009a). La formacion de profesores: bases teoricas para el desarrollo de programas de formacion inicial [Teacher Training: Theoretical Bases for the Development of Preservice Training Programmes]. Revista de Educacion, (350), 15-30. Retrieved from http://dialnet.unirioja. es/servlet/oaiart? codigo $=3038838$.

Esteve-Zarazaga, J.M. (2009b): Politicas de formacion inicial y continua (maestros y secundaria). Critica y propuestas. In Puelles Benitez, M. (coord.). Profesion y vocacion docente. Presente y futuro. Madrid: Biblioteca Nueva - Escuela Julian Besteiro, 139-162.

Gamez-Rebolledo, T. (2015). La formacion inicial del profesorado de educacion primaria y secundaria en Alemania, Espana, Finlandia, Francia y Reino Unido. Estudio Comparado. [Preservice Training of Primary and Secondary School Teachers in Germany, Spain, Finland, France and United Kingdom: Comparative Study]. Revista Espanola de Educacion Comparada, (25), 129-148.

Garii, B. (2008). A Teacher's Job Doesn'T Only Happen in the Classroom: Preservice Teachers, the Classroom, and the School. Action in Teacher Education 30 (1), 81. DOI:10.1080/01626620.20 08.10463483 .

Gonzalez-Faraco, J. C., Perez-Moreno, H. M. \& Jimenez-Vicioso, J. R. (2011). El nuevo modelo formativo del profesorado de Educacion Secundaria y su proceso de implantacion en las Universidades Andaluzas. [The New Training Model of Secondary School Teachers and its Implementation in Andalusian Universities]. Revista de la Facultad de Ciencias de la Educacion, 11, 67-85.

Gonzalez-Peiteado, M. (2014). La Construccion de los Estilos de Ensenanza desde la Formacion Inicial del Profesorado de Educacion Secundaria. [Learning Styles Building in Secondary Education Teachers' Initial Training]. Educatio Siglo XXI 32 (1): 173-192. http://search.proquest.com/ docview/1674695276.

Gonzalez-Sanmamed, M. (2015). El practicum en la formacion del profesorado de secundaria. [The Practicum in the Preservice Training of Secondary School Teachers]. Revista Espanola De Pedagogia, 261, 301-319. 
Gonzalez-Sanmamed, M. (2009). Una nueva oportunidad para la formacion inicial del profesorado de Educacion Secundaria. [A New Opportunity for the Preservice Training of Secondary School Teachers]. Revista de educacion, (350), 57-78. Retrieved from http://dialnet.unirioja.es/servlet/ oaiart? codigo $=3038852$.

Grudnoff, L., Mavis, H. \& Mackisack, V., 2016. Re-Envisaging and Reinvigorating School-University Practicum Partnerships. Asia-Pacific Journal of Teacher Education, 1-14. DOI:10.1080/135986 6X.2016.1201043.

Hascher, T. \& Hagenauer, G., 2016. Openness to Theory and its Importance for PreService Teachers' SelfEfficacy, Emotions and Classroom Behaviour in the Teaching Practicum. International Journal of Educational Research 77: 15-25. DOI:10.1016/j.ijer.2016.02.003. http://www.sciencedirect.com/ science/article/pii/S0883035515303670.

Hernandez-Pina, F. (2014). Evaluacion y acreditacion del profesorado, programas e instituciones educativas. [Assessment and Certification of Teachers, Curricula and Educational Institutions]. Revista electronica interuniversitaria de formacion del profesorado, 17(1), 15-32. Retrieved from http:// dialnet.unirioja.es/servlet/oaiart?codigo $=4736170$.

Jimenez-Segura, F.I., 2013. La Evaluacion del Practicum de Formacion del Profesorado. [Assessment of the Practicum in Preservice Teacher Training]. Universidad de Barcelona.

Krueger, R.A. (1991). El Grupo de Discusion. Guia Practica para la Investigacion Aplicada. [The Discussion Group: Practical Guide for Applied Research]. Madrid, Espana: Piramide.

Lawshe, C. H. (1975). A Quantitative Approach to Content Validity. Personnel Psychology 28 (4): 563-575. DOI:10.1111/j.1744-6570.1975.tb01393.x

Lawson, T., Cakmak, M., Gunduz, M. \& Busher, H. (2015). Research on Teaching Practicum - a Systematic Review. European Journal of Teacher Education 38 (3), 392-407. DOI:10.1080/02619768.2014. 994060.

Lopez Meneses, E., Dominguez Fernandez, G., Alvarez Bonilla, F. J. y Jaen Martinez, A. (2011). Experiencia didactica con estudiantes de postgrado sobre los roles del educador en la Sociedad del Conocimiento y la Comunicacion con tecnologias 2.0. Revista Latinoamericana de Tecnologia Educativa, vol 10 (1), 49-58.

Manso Ayuso, J. \& Martin Ortega, E. (2014). Valoracion del Master de Formacion de Profesorado de Educacion Secundaria: estudio de casos en dos universades. Revista de Educacion 364, Abril-Junio, pp. 145-169. DOI: 10.4438/1988-592X-RE-2014-364-258

Manso, J. (2012). La formacion inicial del profesorado de Educacion Secundaria: Analisis y valoracion del modelo de la LOE. Doctoral Thesis, unpublished. Autonomous University of Madrid.

Martinez, V. G., Zuniga, S., Aquino, P., Sala, A. G. \& Melendez, A. M. (2012). El uso del metodo Delphi como estrategia para la valoracion de indicadores de calidad en programas educativos a distancia. [Using the Delphi Method as a Strategy for the Assessment of Quality Indicators in Distance Education Programmes]. Calidad en la educacion Superior, 3(1), 200-222.

Molina-Ruiz, E. (2008). Analysis of the System of Practicum in Spanish Universities. European Journal of Teacher Education 31 (4):339-366. DOI:10.1080/02619760802420719. http://www.tandfonline. com/doi/abs/10.1080/02619760802420719.

Moon, B. (2006). Practical Experience in Teacher Education: Issues Charting a European Agenda. European Journal of Teacher Education: 217-249. DOI:10.1080/0261976960190302.

Muniz-Rodriguez, L., Velazquez, P.A., Rodriguez-Muniz, L.J. \& Valcke, M. (2016). ¿Hay un Vacio en la Formacion Inicial del Profesorado de Matematicas de Secundaria en Espana Respecto a otros Paises? [Is there a Gap in the Preservice Training of Secondary Math Teachers in Spain as Compared to Other Countries?] Revista De Educacion 372, 111-140. DOI:10.4438/1988-592XRE-2015-372-317. 
Okoli, C. \& Pawlowski, S.D. (2004). The Delphi Method as a Research Tool: An Example, Design Considerations and Applications. Information \& Management 42 (1): 15-29. DOI:10.1016/j. im.2003.11.002. http://www.sciencedirect.com/science/article/pii/S0378720603001794.

Papoulia-Tzelepi, P. (2006). Teaching Practice Curriculum in Teacher Education: A Proposed Outline. European Journal of Teacher Education: 147-162. DOI:10.1080/0261976930160206.

Patton, M.Q., 1987. How to Use Qualitative Methods in Evaluation. United States: SAGE Publications Inc.

Perello, S. (2009). Metodologia de la Investigacion Social [Social Research Methodology]. Madrid: Dykinson.

Roblizo Colmenero, M., Sanchez Perez, M. C., Cozar Gutierrez, R. (2015). El reto de la competencia digital en los futuros docentes de Infantil, Primaria y Secundaria: los estudiantes de Grado y Master de Educacion ante las TIC. Revista Prismasocial, no 15, pp.254-295.

Rorrison, D. (2010). Assessment of the Practicum in Teacher Education: Advocating for the Student Teacher and Questioning the Gatekeepers. Educational Studies 36 (5): 505-519. DOI:10.1080/03055691003729013.

Serrano Rodriguez, R. \& Pontes Pedrajas, A. (2017). Diferencias entre expectativas y logros en las competencias del Practicum del Master de Formacion del Profesorado de Ensenanza Secundaria. Revista Electronica Interuniversitaria de Formacion del Profesorado, 20(1), 1-18. DOI: http://dx.doi. org/10.6018/reifop.20.1.235151

Serrano Rodriguez, Rocio \& Pontes Pedrajas, Alfonso (2015a). Expectativas ante la formacion inicial entre el alumnado del Master de Profesorado de Ensenanza Secundaria. Revista de Investigacion Educativa, 33(2), 489-505. DOI: http://dx.doi.org/10.6018/rie.33.2.203471

Serrano-Rodriguez, R. \& Pontes-Pedrajas, A. (2015b). Nivel De Desarrollo De Las Competencias Y Objetivos Generales Del Master Formacion Del Profesorado De Ensenanza Secundaria. [Level of Development of Competences and General Objectives of the Master's Degree in Teacher Training and Secondary Education]. Perfiles Educativos 37 (150).

Tiana, A. (2013). Los cambios recientes en la formacion inicial del profesorado en Espana: una reforma incompleta. Revista Espanola de Educacion Comparada, 22 (2013), 39-58. DOI: https://doi. org/10.5944/reec.22.2013.9322

Tiana, A. (2011). Politicas de formacion del profesorado y mejora de los sistemas educativos: algunas reflexiones a partir de la experiencia espanola. Revista Fuentes, 11, 2011, 13-27.

Tejada-Fernandez, J., Serrano-Angulo, J., Ruiz-Bueno, C. \& Cebrian-Robles, D. (2015). El proceso de construccion y validacion de los instrumentos de recogida de informacion sobre el practicum y su evaluacion a traves de herramientas tecnologicas. [Building and Validation of Instruments to Collect Information on the Practicum and their Evaluation Based on ICT Tools]. In Rapos-Rivas, M., Munoz-Carril, P., Zabalza Cerdeirina, M.E. Martinez Figueira, A. \& Perez Abellas (Eds.), Documentar y evaluar las experiencias de los estudiantes en las practicas (261-272). Poio, Espana: Andavira Editora.

Toom, A., Husu, J. \& Patrikainen, S. (2015). Student Teachers' Patterns of Reflection in the Context of Teaching Practice. European Journal of Teacher Education, 38(3), 320-340. DOI:10.1080/02619 768.2014.943731

Valdes-Puentes, R., Bolivar-Botia, A. \& Moreno-Verdejo, A. (2015). Una valoracion de la formacion inicial de profesores en Espana: El Master en Educacion Secundaria. [An Assessment of Preservice Teacher Training in Spain]. Educacao em Revista, 31(3).

Zabalza-Beraza, M. A. (2006). Aspectos Cualitativos de la Evaluacion del Practicum: Evaluacion del Programa y de los Estudiantes. [Qualitative Aspects of Practicum Assessment: Evaluation of the Programme and Students]. European Journal of Teacher Education 19 (3): 293-302. DOI:10.1080/0261976960190308.

Zeichner, K. \& Wray, S. (2001). The Teaching Portfolio in US Teacher Education Programs: What We Know and What We Need to Know. Teaching and Teacher Education, 17(5), 613-621. DOI:10.1016/ S0742-051X(01)00017-8 